\title{
Trykforskel i nordjysk Skrivekridt - findes der adskilte grundvandsmagasiner?
}

Af geofysiker Henrik Andersen og hydrogeolog Karsten Juul, begge Hedeselskabet Miljø og Energi A/S, og geolog Anne Mette Nielsen, Nordjyllands Amt

På flere lokaliteter med åbne kalkboringer i Himmerland er der identificeret forskelligt trykniveau i forskellige dybder i kalken. Dette er observeret ved Voldsted nordøst for Støvring og ved Ellidshøj sydvest for Svenstrup. Vores antagelse er, at der findes to magasiner i kalken med forskelligt trykniveau-adskilt af en lavpermeabel barriere.

Geologisk set er det meste af området mellem Limfjorden og Mariager Fjord karakteriseret ved, at kalkoverfladen som følge af det neogene opløft ligger højt, mange steder over kote 25. I området syd for Aalborg er den terrænnære geologi stærkt afhængig af et kompliceret system af forkastninger, som har givet området dets karakteristiske udseende med højtliggende "kalkøer" omgivet af dale med langt større mægtigheder af glaciale aflejringer. Området ligger midt i det, der kaldes "nitratbæltet", hvor grundvandet har stor følsomhed over for udvaskning af nitrat pga. meget ringe reduktionskapacitet $i$ dæklagene over grundvandet.

Strømningsforholdene i den faste kalk afviger markant fra strømningen i løse sedimenter. Kalkbjergarter er karakteriseret ved at have høj porøsitet, men lav permeabilitet $\mathrm{i}$ kalkmatriks, men desuden findes en sekundær porøsitet i form af sprækker, som har meget høj permeabilitet. Det betyder helt generelt, at den altdominerende vandstrømning i kalkbjergarter er forbundet med tilstedeværelsen af sprækker. Den sprækkedominerede strømning giver anledning til meget komplicerede og ofte uforudseelige hydrauliske forhold på boringsniveau.

Indvindingsboringer i kalk er normalt udbygget med et forerør af metal fra terræn gennem de kvartære og tertiære sedimenter til et stykke ned i kalken. Herunder står boringen "åben" over et ofte meget langt interval i kalken. Enkelte kalkboringer er forsynet med filterrør og gruskastning på samme vis som boringer i sand- eller grusmagasiner.

\section{Lavpermeabel sekvens}

Det er ikke helt ligetil at konstatere tryk-

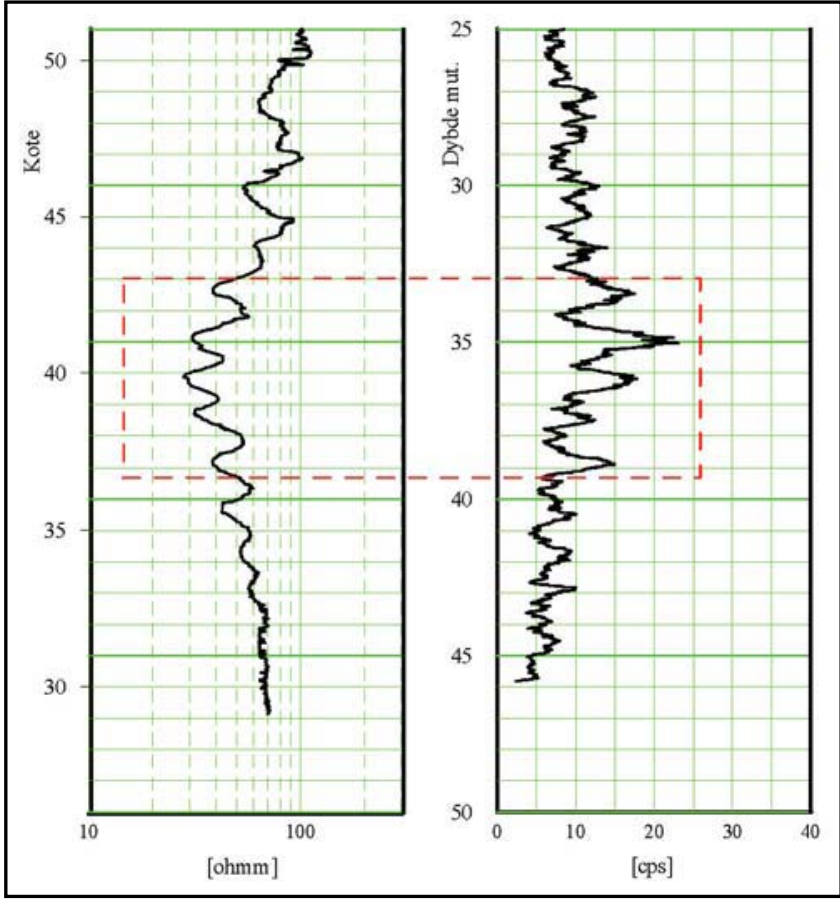

forskelle i en og samme boring, men ved brug af geofysisk borehulslogging og særligt af flowlog med og uden pumpning har det flere steder i Nordjylland vist sig, at vandet igennem boringen strømmer fra et niveau til et andet. Når der foregår en strømning i boringen - uden der pumpes, må der være en hydraulisk barriere i formationen mellem de niveauer, hvor strømningen foregår, som forsinker eller forhindrer udligning af trykforskelle - altså der må være en lavpermeabel sekvens. Ved måling af potentialeforskel i en boring med flere filtre er der fundet trykforskel på ca. 2 meter.

Ved supplerende geofysisk borehulslogging af sekvensen, som rummer den hydrauliske barriere, er der målt en serie markante tælletal med en naturlig gammalog samt tilsvarende markante variationer i resistivitetslog og induktionslog (figuren ovenfor). Den lavpermeable sekvens giver sig således til kende ved meget karakteristiske forløb af den naturlige gammalog med 4 markante toppe, hvor tælletallene overstiger 10 counts per second (cps) adskilt af tynde sekvenser med mere moderate tælletal mellem 5-10 cps. Tilsvarende ses lave modstande vekslende med modstande nær niveauet i den øvrige del af kalken. Disse loggingsignature er genkendelige fra boring tilboring.
Hermed er der fundet en markant og genkendelig sekvens i kalken, der tilsyneladende udgør en barriere mellem to enheder $i$ det primære magasin i den nordjyske kalk. Barrieren har muligvis regional udstrækning.

Nordjyllands Amt har ladet indsamle loggingresultater fra kalkboringer inden for et større området syd for Aalborg. De indsamlede resultater er suppleret med borehulslogging i udvalgte boringer. Borehulslogging er udført som naturlig gammalog og induktionslog. Et profil gennem området er vist i figuren øverst næste side. På profilet $\mathrm{i}$ figuren ses alle dybere boringer, der findes inden for 50 meter fra profillinien. Langt de fleste korte boringer er udeladt på profilet.

\section{Foreløbige resultater}

Af profilet fremgår, at der trods en stor variation i både terræn og kalkoverflade tilsyneladende er lineær sammenhæng af sekvensens placering over en række boringer. At der er sammenhæn mellem de to tætliggende boringer ved Ellidshøj Kildeplads (på profilet ses kun DGU nr. 34.1626) er ikke så overraskende, mens sammenhængen fra Godthåb til Flamsted Mark er meget bemærkelsesværdig. Her ses identiske log-signaturer i både induktions- og naturlig gammalog trods $10 \mathrm{~km}$ afstand mellem boringerne.

Der er gjort en lang række andre fund af 


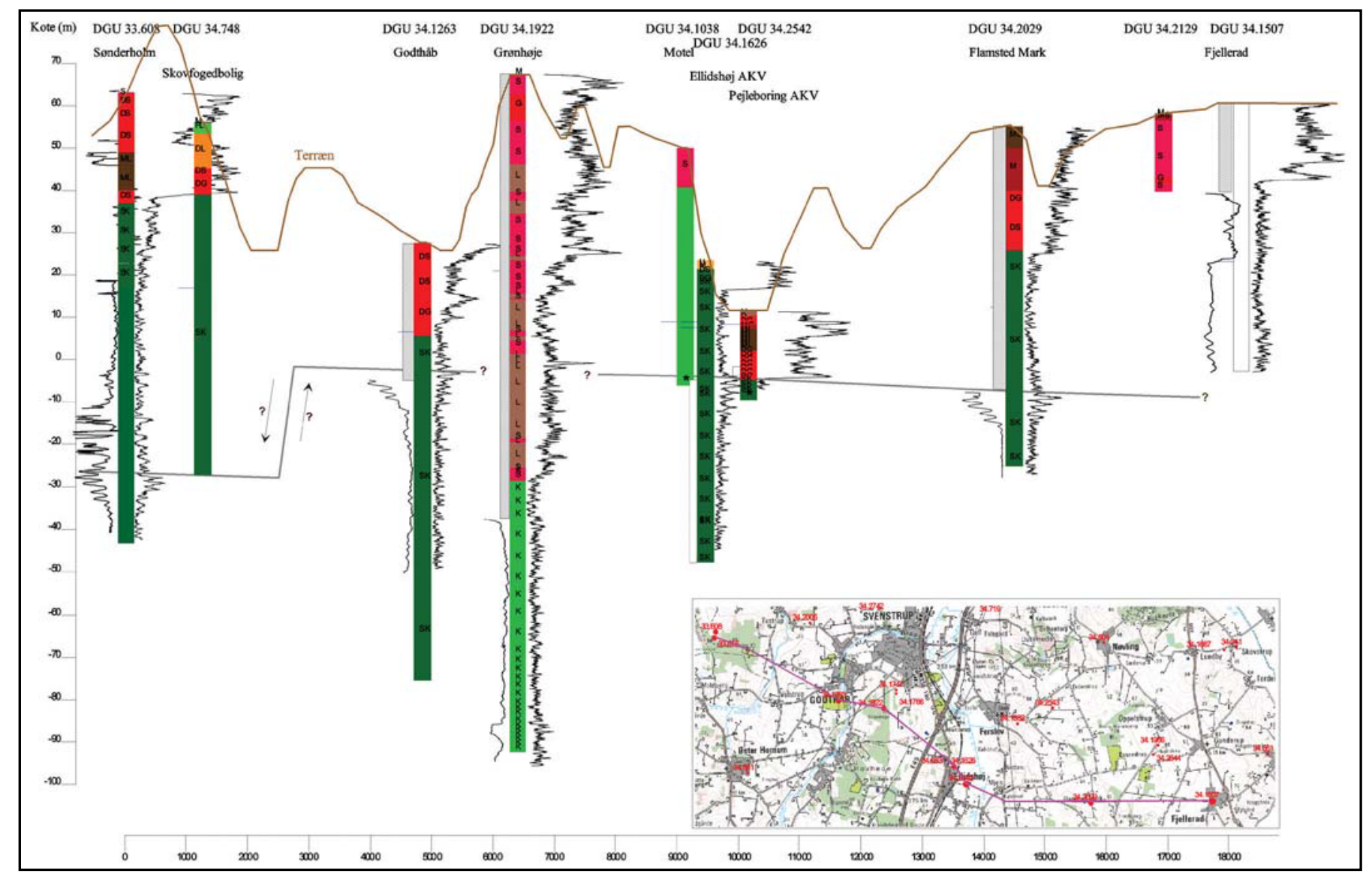

$18 \mathrm{~km}$ langt profil gennem det meste af interesseområdet. Det er iøjnefaldende så god lighed der findes mellem logsignaturen ved Sønderholm, Godthåb, Ellidshøj og ved Flamsted Mark. Der ses meget varierende terrcenflade og kalkoverflade. Derimod er der tilsyneladende linecer sammenhang af den fundne sekvens placering $i$ en rakke boringer. (Grafik: Forfatterne)

sekvensen, hvor den findes i meget anderledes dybder (koter), som ikke kan forbindes med det skitserede. Fx er sekvensen fundet med top omkring kote -18 i tre boringer på Flødal Kildeplads ca. $700 \mathrm{~m}$ nordøst for DGU nr. 34.1922 på profilet, og med top i kote $-40 \mathrm{i}$ boringen med DGU nr. $34.2698 \mathrm{i}$ Volsted Plantage ca. 1,7 km sydvest for DGU nr. 34.2029 ved Flamsted Mark.

De observerede forskydninger af niveauet for sekvensen hænger sandsynligvis sammen med det komplicerede forkastningssystem $i$ området. I den vestlige ende på profilet i figur 2 ses DGU 33.608, hvor sekvensen findes godt 20 meter dybere end niveauet for de øvrige fund. Fortolkningen af en forkastning på profil syd mellem Sønderholm Plantage og Godthåb er kun et løst gæt, men er placeret, hvor profilet krydser Hasseris Å. Idet der formentlig er en sammenhæng mellem vandløb og forkastninger i kalken $\mathrm{i}$ hele området. Ved Gudumholm øst for profilet findes sekvensen med top i kote -13, hvilket stemmer overordentligt godt overens med den lineære sammenhæng på profilet.

Undersøgelsen er endnu ikke ført til ende, men de foreløbige resultater giver kraftige indikationer om, at der findes en udbredt "geofysisk marker" i skrivekridt i området syd for Aalborg. Det billede, der tegner sig, er, at sekvensen, der rummer denne marker findes udbredt i området, og hælder ganske svagt fra vest mod øst (ca. $0,5 \%$ fald). Der er desuden antydninger af, at sekvensen også har en hældning fra nord mod syd. Placeringen af sekvensen kan anvendes til strukturel kortlægning, og dermed til opnåelse af en bedre forståelse af de hydrauliske og vandkemiske sammenhænge $\mathrm{i}$ område.

\section{Det videre arbejde}

De næste skridt er at identificere de geologiske bestanddele, som giver anledning til en mere tæt og lavpermeabel kalk, der geofysisk kan karakteriseres ved, at den i sekvenser har et betydeligt højere indhold af radioaktive komponenter end den omgivende formation og i samme sekvenser udviser et lavere modstandsniveau end den omgivende formation.

En nærliggende fortolkning af den lavpermeable sekvens er at pege på et forhøjet indhold af ler i de anormale sekvenser. Idet de fleste lermineraler netop er karakteriseret ved højere indhold af radioaktive isotoper af grundstofferne kalium og thorium end kalk, og lermineraler har samtidig langt bedre halvledende egenskaber end kalk. Altså ville resultatet af sekvenser med højere lerindhold være højere tælletal i den naturlige gammalog samt et lavere mod- standsniveau end den omgivende formation.

Hvordan kan der optræde sekvenser med forhøjet lerindhold i skrivekridt, hvor aflejringsforholdene normalt betragtes som værende meget rolige og ensartede? Forklaringen skal formentlig søges i diagenetiske forhold. Eller måske netop i at diagenesen ikke er forløbet normalt. Således der kun er sket en kompaktion af sedimentet, men cementeringen og omkrystallisering er helt eller delvist udeblevet. Derved kan terrigene indslag forblive i de sekvenser, de oprindeligt er aflejret i.

\section{Fremtidige perspektiver}

Såfremt der findes en lavpermeabel enhed $i$ kalken $i$ Nordjylland med større udstrcekning, vil det have stor betydning for: - Hydrauliske bestemmelser i kalk - T-værdier-valg af pejleboringer-potentialekort

- Vandkemisk kortlægning-lavere iltindhold?-nitratforurening-pesticidforurening

For geologisk forståelse:

- Sen Kridt - intern markør - hvad siger oliegeologerne fra Nordsøen?

-Mulig sammenhæng med miljømæssige skift ved overgangen mellem Kridt og Tertiær? 